\title{
Biallelic expression of imprinted genes in the mouse germ line: implications for erasure, establishment, and mechanisms of genomic imprinting
}

\author{
Piroska E. Szabó and Jeffrey R. Mann \\ Division off Biology, Beckman Research Institute of the City of Hope, Duarte, California 91010 USA
}

\begin{abstract}
Genomic imprinting in mammals determines parental-specific (monoallelic) expression of a relatively small number of genes during development. Imprinting must logically be imparted in the germ line, where inherited maternal and paternal imprinting is erased and new imprinting established according to the individual's sex. We have assessed the allele-specific expression of four imprinted genes, two of which exhibit maternal-specific (H19 and Igf2r) and two of which exhibit paternal-specific (Igf2 and Snrpn) monoallelic somatic expression, in the germ line of $F_{1}$ hybrid mice utilizing quantitative RT-PCR single-nucleotide primer extension assays. The expression of each gene was biallelic in the female and male germ line from the time that migratory mitotic PGCs entered the embryonic genital ridge and throughout gametogenesis, except that H19 RNA was not detected late in gametogenesis. These findings demonstrate that inherited imprinting is erased, or not recognized, in germ cells by the time of genital ridge colonization; also that new imprinting may not be established until late in gametogenesis, or that it is incomplete or not recognized at this stage. Regardless of imprinting status, a generalized neutralization of imprinting is evident in the germ line, associated with the totipotent state of this unique cell lineage.
\end{abstract}

[Key Words: Imprinting; germ line; embryo; mouse genetics; gene expression; quantitative PCR]

Received May 5, 1995; revised version accepted June 23, 1995.

The epigenetic phenomenon of genomic imprinting determines an inequality of the maternal and paternal genomes in mammals. This is evident from the developmental failure of mouse embryos with two maternal or two paternal genomes, termed parthenogenetic and androgenetic, respectively, and of embryos with uniparental duplication of autosome regions (Lyon and Glenister 1977; Mann and Lovell-Badge 1984; McGrath and Solter 1984; Surani et al. 1984; Cattanach and Kirk 1985). Imprinting is also evident in the preferential inactivation of the paternally derived $\mathrm{X}$ chromosome in extraembryonic components of the conceptus (Takagi et al. 1978). As defined by developmental success, there is evidence that two maternally imprinted $\mathrm{X}$ chromosomes can adversely affect development, although the observations suggest that the majority of imprints affecting development reside on the autosomes (Mann and Lovell-Badge 1987, 1988; Kaufman et al. 1989; Takagi and Abe 1990). Only a well-defined minor subset of the autosomal component is involved, as abnormal phenotypes and lethality of mice with maternal or paternal duplication is observed for only a small number of autosome regions (Beechey and Cattanach 1995).

It is now generally believed that imprinting influences development through the imposition of parent-of-origin- dependent gene activity. A growing number of genes that exhibit a monoallelic $(+1-)$ mode of expression are being identified (for list, see Beechey and Cattanach 1995), and at least some of these genes appear to be biallelically expressed $(+/+)$ or inactive $(-/-)$ in embryos and neonates with uniparental inheritance of these genes (Ferguson-Smith et al. 1991, 1993; Cattanach et al. 1992; Sasaki et al. 1992). Some instances have been documented in which the aberrant expression of such genes is known to have a deleterious developmental effect, namely, a $-1-$ mode of expression of insulin-like growth factor 2, Igf2 (small size, DeChiara et al. 1991), insulin-like growth factor 2 receptor, Igf2r (perinatal lethality, Lau et al. 1994; Wang et al. 1994), murine achaete-scute homolog 2, Mash2 (midgestation lethality, Guillemot et al. 1994, 1995), and H19 (large size, Leighton et al. 1995). These observations demonstrate the necessity for expression of at least some imprinted genes, although it is unclear at this stage if their monoallelic or "imprinted" mode per se is always a necessity for normal development. It does appear important at least for Igf2, as a $+1+$ mode of expression of this gene, brought about by deletion of the $H 19$ gene region, leads to increased size (Leighton et al. 1995).

Because at least some imprints appear necessary for 
normal somatic and extraembryonic development, it is pertinent to ask whether imprinting is also a feature of, and perhaps also necessary for, germ cell development. Whereas functional oocytes of parthenogenetic origin can be obtained in chimeras (Stevens 1978; Allen et al. 1994), it is possible that deficient developmental cues in parthenogenetic germ cells may be compensated by association with normal or wild-type germ cells. On this point, it has been discovered recently that migratory primordial germ cells (PGCs) become associated by a network of cytoplasmic bridges upon approaching the genital ridge, and this network persists after entry into the gonad (Gomperts et al. 1994). Whether androgenetic germ cells can be formed and rescued in chimeras remains to be determined, although the very low level contribution of the androgenetic component generally precludes this possibility (Mann et al. 1990). Also, it is necessary to ask for how long imprinting may persist in the germ line, as inherited maternal and paternal imprints must be erased at some stage, and new imprints established according to the individual's sex. To summarize germ cell development, the progenitor cells of the germ line reside at the proximal portion of the primitive ectoderm of the 6.5 days postcoitus (dpc) (pregastrulation stage) egg cylinder, and PGCs are first seen as a discrete alkaline phosphatase positive population of $\sim 100$ cells in the base of the extraembryonic allantois at $7.5 \mathrm{dpc}$ (late gastrulation stage). Here, as judged by the pattern of intracellular alkaline phosphatase staining, they undergo maturation and move, probably passively, into the embryonic hindgut endoderm by $8.5 \mathrm{dpc}$ (early somite stage). From this location, they migrate actively to the genital ridges, and probably all PGCs have arrived by $11.5 \mathrm{dpc}$ when the genital ridge is still sexually indifferent. Mitosis ceases in the female germ line at $13.5 \mathrm{dpc}$, when meiosis commences, and in the male germ line at $14.0 \mathrm{dpc}$. Meiosis in the latter commences at 7.0 days postpartum (dpp) (Eddy et al. 1981; Ginsburg et al. 1990; Hogan et al. 1994; Lawson and Hage 1994).

Although parental-specific monoallelic expression in the soma is indicative of the presence of imprinting, biallelic expression of Igf2 in the choroid plexus, leptomeninges (DeChiara et al. 1991), and human tumors (Ogawa et al. 1993; Rainier et al. 1993) has been interpreted to represent imprinting loss. On this same basis of allele-specific expression, we have attempted to gain information about the existence of imprinting in the germ line and its times of erasure and establishment: Simplistically, (1) somatic patterns of allele-specific expression in both germ lines would be indicative of the presence of inherited imprints, (2) biallelic expression in both germ lines would be indicative of the loss of inherited imprints, and (3) appropriate sex-specific biallelic expression, for example, for an imprinted gene paternally expressed in the soma, biallelic expression in the male, and lack of expression in the female germ line, would be indicative of the establishment of new imprints. These expectations are based on the assumption that the presence of imprinting will always result in parental-specific expression, which may not necessarily be the case /dis- cussed later). Thus, for two imprinted genes that are somatically maternally expressed [H19 (Bartolomei et al. 1991) and Igf2r (Barlow et al. 1991)], and a further two that are somatically paternally expressed [Igf2 (DeChiara et al. 1991) and small nuclear ribonucleoprotein $\mathbf{N}$, Snrpn (Leff et al. 1992; Cattanach et al. 1992)], we provide a quantitative assessment of allele-specific expression throughout germ cell development. Implications of the findings for the presence of imprinting in germ cells, mechanisms of imprinting, and germ cell development are discussed.

\section{Results}

\section{Quantitative RT-PCR SNuPE assays}

The assay (Singer-Sam et al. 1992; Buzin et al. 1994) is based on a single known nucleotide difference between allelic RNAs. Necessary sequence differences were found in two inbred strains, C57BL/6J (B6) (Mus musculus) and ferally derived CAST/Ei (CS) (M. musculus castaneus), and an assay was developed for each gene. Results of mixing experiments show that all four assays are rigorously quantitative when utilizing small quantities of total RNA (Fig. 1A-C; Table 1). These assays were used to determine the relative proportions of maternal and paternal allele-specific RNA in intersubspecific $(\mathrm{B} 6 \times \mathrm{CS}) \mathrm{F}_{1}, \mathrm{~B}_{6 \mathrm{CSF}}$, hybrid embryos.

\section{Biallelic expression in postmigratory PGCs of the morphologically sexually indifferent genital ridge}

In postmigratory PGCs purified from the $11.5 \mathrm{dpc}$ sexually indifferent genital ridge, all four genes examined were expressed biallelically (Fig. 2A). Analyses were also conducted on the whole $11.5 \mathrm{dpc}$ genital ridge, which is comprised of both PGCs and somatic cells (Fig. 2A). For $H 19$ and Igf2, monoallelic expression was observed, demonstrating that the somatic cell component exhibited monoallelic expression of these two genes. To account for the complete quenching of the PGC-derived paternal $H 19$ and maternal Igf2 signals, the total somatic $H 19$ and Igf2 RNA must have been considerably higher than that derived from the germ cell component. This relative difference translates approximately into the amount of RNA per cell, as PGCs comprise a significant proportion of the genital ridge [a crude estimate of $50 \%$ by volume based on our estimates of $11.5 \mathrm{dpc}$ genital ridge volume $\left(13 \times 10^{6} \mu \mathrm{m}^{3}\right)$, PGC cell diameter (14-18 $\mu \mathrm{m})$, and the number of PGCs present in the $11.5 \mathrm{dpc}$ genital ridge (3000; Tam and Snow 1981)]. In contrast to $H 19$ and $I g f 2$, the whole genital ridge exhibited biallelic expression of $I g f 2 r$ and Snrpn (Fig. 2A,B). This result is consistent with comparable amounts of total $I g f 2 r$ and Snrpn RNA in the PGC and somatic components, assuming that these two genes were expressed monoallelically in the latter: These two genes, as well as Igf2 and $H 19$, were expressed monoallelically in the adjacent mesonephros, the tissue of origin of the somatic genital 
C

A

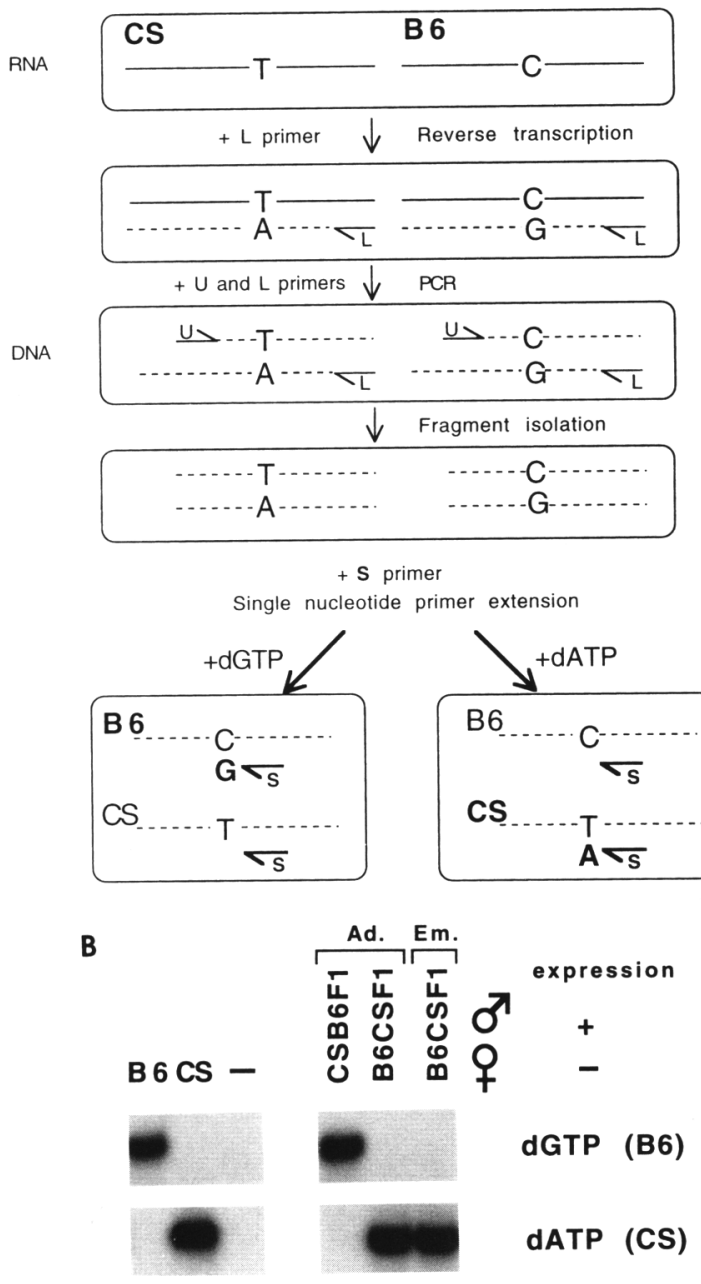

$\lg f 2 r$

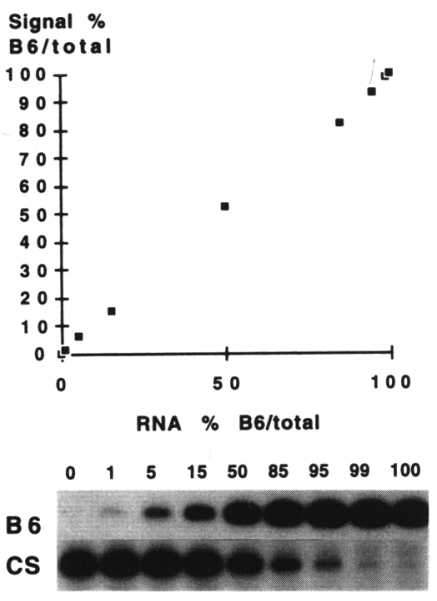

$\lg f 2$

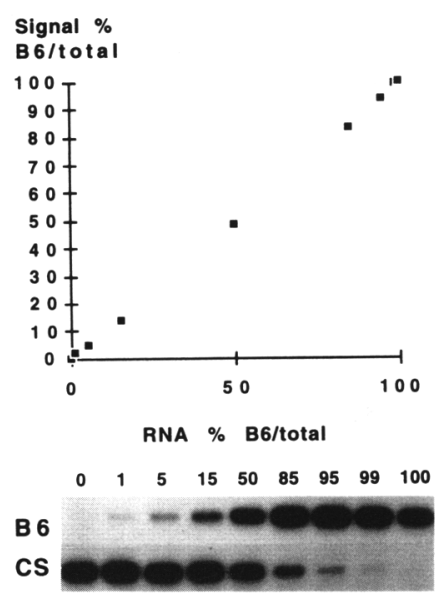

$H 19$

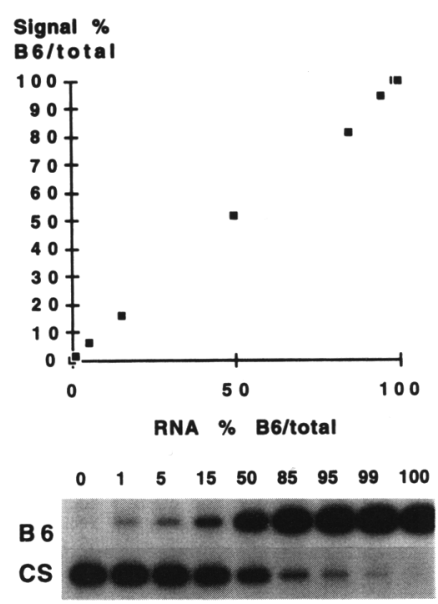

Snrpn

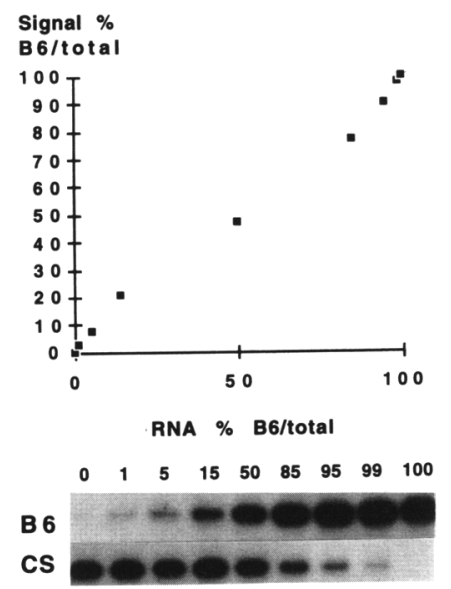

Figure 1. RT-PCR single-nucleotide primer extension (SNuPE) assay for allele-specific RNA quantitation. $(A)$ Outline of assay: RT-PCR is performed on total RNA isolated from $F_{1}$ tissue that potentially contains two allelic species of RNAs, B6 and CS, with lower $(\mathrm{L})$ and upper $(\mathrm{U})$ primers. These primers span an exon region that harbors a single defined base difference between the two mouse strains and at least one intron (see Table 1 footnote). The relative proportions of amplified allele-specific DNA products of RT-PCR reflect the original relative proportions of the two allele-specific RNAs. DNA products are isolated, and each of two equal aliquots is subjected to SNuPE with (1) a SNuPE primer that abuts the known base difference, and (2) a radioactive nucleotide that will incorporate into either the B6- or the CS-amplified DNA. The degree of radioactive incorporation is quantified in each of the two reactions (for details, see below), and the relative incorporation represents the relative proportions of allele-specific RNAs. (B) Example of assay: RT-PCR specific for Snrpn RNA was performed on $10 \mathrm{ng}$ of total RNA isolated from $\mathrm{CSB}_{1} \mathrm{~F}_{1}$ (CS was maternal parent) and the reciprocal hybrid adult (Ad.) brain, and $\mathrm{B} \mathrm{CSF}_{1}$ hybrid (B6 was maternal parent) $13.5 \mathrm{dpc}$ whole embryo (Em.). Isolated DNA products of RT-PCR were subjected to SNuPE with [ $\left.{ }^{32} \mathrm{P}\right] \mathrm{dGTP}$ (top, B6-specific incorporation) or [ ${ }^{32} \mathrm{P}$ ) dATP (bottom, CS-specific incorporation). This shows that (1) there was no incorporation into the nonspecific DNA template in any of the lanes, and (2) in these tissues, maternal Snrpn RNA is not detectable. $|C|$ Assessment of quantitative abilities of assays: For each gene, an RNA reconstruction experiment is shown below the graph. Total RNA isolated from B6 and CS $13.5 \mathrm{dpc}$ embryos was mixed together in different proportions as indicated. (0) 0\% B6 and 100\% CS RNA; (1) 1\% B6 and 99\% CS RNA; (5) 5\% B6 and 95\% CS RNA, etc., and RT-PCR SNuPE performed according to Singer-Sam et al. (1992) and as outlined in $A$. Total RNA used was $2 \mathrm{ng}$ of $I g f 2 r ; 0.5 \mathrm{ng}$ of $H 19 ; 0.5 \mathrm{ng}$ of $I g f 2,10 \mathrm{ng}$ of Snrpn. The values obtained show that for all genes the relationship was linear ( $R^{2}$ of correlation is $>0.99$ in all cases). After electrophoresis, each band was quantified with a PhosphorImager, and autoradiographs were made for the separate B6- and CS-specific gels for production of figures. Autoradiographic exposure times were adjusted so that the $100 \%$ B6 and $100 \%$ CS bands gave approximately the same degree of exposure. Calculation of actual relative proportions of B6 RNA (y axis on graph) was performed using the PhosphorImager data. First, the B6-specific background counts (position of $0 \%$ sample) were subtracted from counts obtained for each B6-specific band, and likewise for the CS-specific data. Second, the B6-specific counts were multiplied by counts obtained for $50 \%$ CS RNA divided by the values obtained for $50 \%$ B 6 RNA. This adjustment eliminated bias coming from possible differences in incorporation efficiencies of the two radionucleotides and from differences in the number of nucleotides that incorporate (see Table 1). Data in the remaining figures were adjusted in the same way using the controls included. 
Table 1. RT-PCR and SNuPE information

\begin{tabular}{|c|c|c|c|c|c|c|}
\hline \multirow[b]{2}{*}{ Gene } & \multirow[b]{2}{*}{ Primers } & \multirow[b]{2}{*}{ Exon } & \multicolumn{2}{|c|}{$\begin{array}{l}\text { Fragment size }(\mathrm{bp}) \\
\text { amplified from }\end{array}$} & \multicolumn{2}{|c|}{$\begin{array}{l}\text { Incorporating } \\
\text { radionucleotides }\end{array}$} \\
\hline & & & DNA & mRNA & B6 & CS \\
\hline$I g f 2 r$ & $\begin{array}{l}\text { U, 5'-CTGGAGGTGATGAGTGTAGCTCTGGC-3' } \\
\text { L, 5'-GAGTGACGAGCCAACACAGACAGGTC-3' } \\
\text { S, 5'-TGCGGGGCCATC-3' }\end{array}$ & $\begin{array}{l}10 \\
11\end{array}$ & $\sim 6,000$ & 235 & AA & G \\
\hline H19 & $\begin{array}{l}\text { U, 5'-CCACTACACTACCTGCCTCAGAATCTGC-3' } \\
\text { L, 5'-GGTGGGTACTGGGGCAGCATTG-3' } \\
\text { S, 5'-ACATTCATACGGAGAGACTC-3' }\end{array}$ & $\begin{array}{l}4 \\
5\end{array}$ & 474 & 413 & $\mathrm{AAA}$ & $\mathrm{C}$ \\
\hline Igf2 & $\begin{array}{l}\text { U, 5'-GACGTGTCTACCTCTCAGGCCGTACTT-3' } \\
\text { L, 5'-GGGTGTCAATTGGGTTGTTTAGAGCCA-3' } \\
\text { S, 5'-TCAAATTTGGTTTTTTAGAA-3' }\end{array}$ & $\begin{array}{l}5 \\
6\end{array}$ & 735 & 492 & $\mathrm{C}$ & $\mathrm{TT}$ \\
\hline Snrpn & $\begin{array}{l}\text { U, 5'-TGCTGCTGTTGCTGCTACTG-3' } \\
\text { L, 5'-GCAGTAAGAGGGGTCAAAAGC-3' } \\
\text { S, 5'-CAATTTCACAAGAAGCATT-3' }\end{array}$ & $\begin{array}{l}6 \\
8\end{array}$ & $\sim 2,000$ & 356 & G & A \\
\hline $\begin{array}{l}(\mathrm{U}, \mathrm{L}) \\
\text { genom } \\
\text { RNA- } \\
\text { that ir } \\
\text { the tw } \\
\text { with } \mathrm{t} \\
\text { by Pet } \\
\text { (Gerre }\end{array}$ & $\begin{array}{l}\text { per and lower RT-PCR primers, (S) SNuPE prime } \\
\text { DNA would be separated from the RNA-specific } \\
\text { ecific fragment lengths. In practice, genomic DN } \\
\text { orporate into B6- or CS-amplified DNA with SNu } \\
\text { different mouse strains, exon fragments were amp } \\
\text { TA Cloning Kit (Invitrogen, San Diego, CA) for } \\
\text { Rotwein prior to publication (Szebenyi and Rotw } \\
\text { et al. 1991). }\end{array}$ & $\begin{array}{l}\text { eal to d } \\
\text { er size; } \\
\text { served } \\
\text { l. To o } \\
\text { r total F } \\
\text { mation } \\
\text { al. } 198\end{array}$ & $\begin{array}{l}\text { ferent ex } \\
\text { ote the } \\
\text { Incorpor } \\
\text { tain nec } \\
\text { NA and } \\
\text { or prime } \\
\text {; Igf2) ( }\end{array}$ & $\begin{array}{l}\text { Is; thus, } p \\
\text { erence in } \\
\text { ng radion } \\
\text { ary seque } \\
\text { cloned in } \\
\text { lesign; (Ig } \\
\text { twein and }\end{array}$ & $\begin{array}{l}\text { entially } \\
\text { enomic } \\
\text { leotides } \\
\text { ce infor } \\
\text { the pC } \\
\text { r) kindl } \\
\text { fall } 199\end{array}$ & $\begin{array}{l}\text { plified } \\
\text { A- and } \\
\text { those } \\
\text { on for } \\
\text { vector } \\
\text { ovided } \\
\text { Snrpn) }\end{array}$ \\
\hline
\end{tabular}

ridge. Also, they were expressed monoallelically in ovarian follicle and testicular Sertoli cells (see below), which are the differentiated derivatives of the $11.5 \mathrm{dpc}$ germ cell supporting cell lineage.

\section{Biallelic and sexually indifferent expression of imprinted genes in the developing ovary and testis, and in oocytes and spermatogenic cells}

The analysis of the whole gonad and mesonephros conducted at $11.5 \mathrm{dpc}$ was also conducted on sexually dimorphic gonads at 12.5-15.5 dpc (Fig. 3A,B). Ovary and testis exhibited biallelic expression of $I g f 2 r$ and Snrpn, as was observed at $11.5 \mathrm{dpc}$. Differences in the degree of bias in allele specific expression obtained, for example, in testis, maternal Snrpn RNA was $50 \%$ of the total at $12.5 \mathrm{dpc}$, and $9 \%$ of the total at $15.5 \mathrm{dpc}$, may have reflected relative changes in germ cells and somatic cells with respect to total expression level, and/or cell number. Taking into account the fact that the mesonephros and developing metanephros (m'nephros) continued to display monoallelic expression of all four imprinted genes (Fig. 3A,B), these results strongly suggest that biallelic expression in the germ line of at least Igf $2 \mathrm{r}$ and Snrpn continued in the female after the onset and arrest of meiosis at $13.5 \mathrm{dpc}$ and in the male after mitotic arrest at $14.0 \mathrm{dpc}$. Ovary and testis at 12.5-15.5 dpc exhibited monoallelic expression of $H 19$ and Igf2 (Fig. 3A,B), as was observed at $11.5 \mathrm{dpc}$. Although we did not isolate germ cells at these stages to examine allele-specific expression, it is probable that continuing biallelic expression in this component was again quenched by considerably higher total amounts of somatic RNA.

Biallelic expression of Igf2r, Igf2, and Snrpn in ovulated unfertilized oocytes of superovulated adult females, and monoallelic expression of these same genes in somatic follicle cells that surrounded these oocytes, was observed (Fig. 3A); we could not detect H19 RNA in either cell type. In the whole postpartum testis, which is comprised of spermatogenic and somatic cells, the allelespecific expression pattern of the four genes at $6.0 \mathrm{dpp}$ was similar to the situation in the embryonic testis, in that monoallelic expression of $I g f 2$ and $H 19$, and biallelic expression of Igf2r and Snrpn, was observed (Fig. 4A). In comparison, monoallelic expression of all four genes was observed in the kidney (Fig. 4A). Igf2 and H19 displayed biallelic expression in the testis from 10.0 to $16.0 \mathrm{dpp}$ (Fig. 4A). This probably reflected a gradual accumulation of biallelically expressing spermatogenic cell types, beginning with the onset of meiosis at $7.0 \mathrm{dpp}$. Biallelic expression in the germ cell component of the postpartum testis was confirmed in purified spermatogenic cell types: All four genes were biallelically expressed in mitotic spermatogonia, purified from $7.0 \mathrm{dpp}$ testes. $I g f 2 r$, 
A

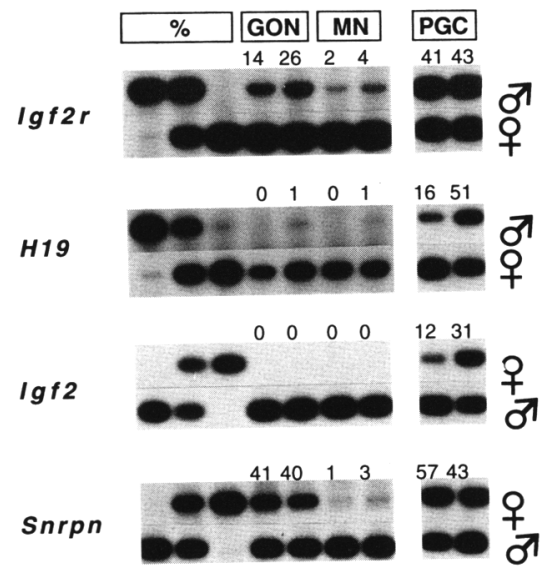

B

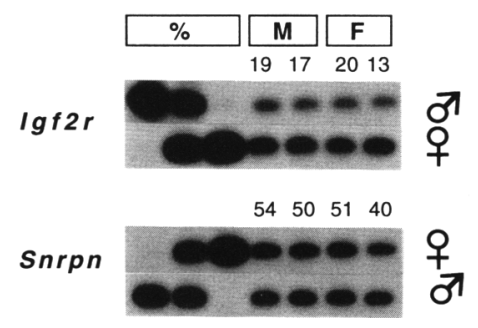

Figure 2. Allele-specific expression in sexually indifferent 11.5 dpc embryonic gonads. (A) Unsexed embryos. (GON) Whole gonad; (MN) mesonephros; (PGC) purified PGCs. The two lanes

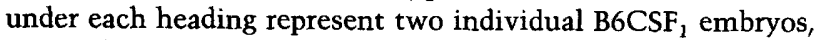
except for PGC, where cells were purified from groups of $\sim 10$ gonads. RT-PCR was performed on one-fifth of the total RNA obtained per gonad and mesonephros, and on $\sim 100$ PGCs purified to homogeneity by micromanipulation (see Materials and methods|. Each imprinted gene is represented by two rows of autoradiograph bands, with the top and bottom representing the presumptive inactive and active alleles, respectively, with the parental origin given at right. The number above each band is the amount of RNA of the presumptive inactive allele expressed as a percentage of the total amount, rounded off as follows: $0 \%$, $0.49 \%$ or less, and $1 \%, 0.5 \%$ to $1.49 \%$, etc. The first three lanes (labeled \%) are RNA quantitation controls performed along with the experimentals so as to allow for the adjustment of experimental values according to the legend to Fig. 1C: (1) $0 \%$ B6 and $100 \%$ CS RNA; (2) $50 \%$ B6 and $50 \%$ CS RNA; (3) $100 \%$ B6 and 0\% CS RNA. (B) Sexed embryos. (M) Male whole gonad; (F) female whole gonad. Before carrying out RT-PCR SNuPE assays, the sexes of embryos were determined using a PCR assay for the Y chromosome-linked Zfy gene (Singer-Sam et al. 1990). Other details are as described in $A$.

Igf2, and Snrpn were biallelically expressed in meiotic pachytene spermatocytes, purified from adult testes, although H19 RNA was not detected (Fig. 4B). RNA of both allelic forms of Igf2r, Igf2, and Snrpn was also de- tected in groups of postmeiotic haploid round spermatids, purified from adult testes, whereas H19 RNA was again not detected (Fig. 4B). Monoallelic expression in the somatic component was evident for Igf2 and $H 19$ in the analysis of whole testis at $6.0 \mathrm{dpp}$ (Fig. 4A), and for Ig2r and Snrpn in the examination of Sertoli cells purified from 7.0 dpp testis (Fig. 4B). Sertoli cells also exhibited monoallelic expression of Igf2 and strongly biased allele-specific expression of $H 19$ (Fig. 4B).

The fact that all four genes were biallelically expressed in the whole 10.0 to 16.0 dpp testis (Fig. 4A) demonstrates that the total RNA of each gene in the germ cell component was comparable to that in the somatic cell

A

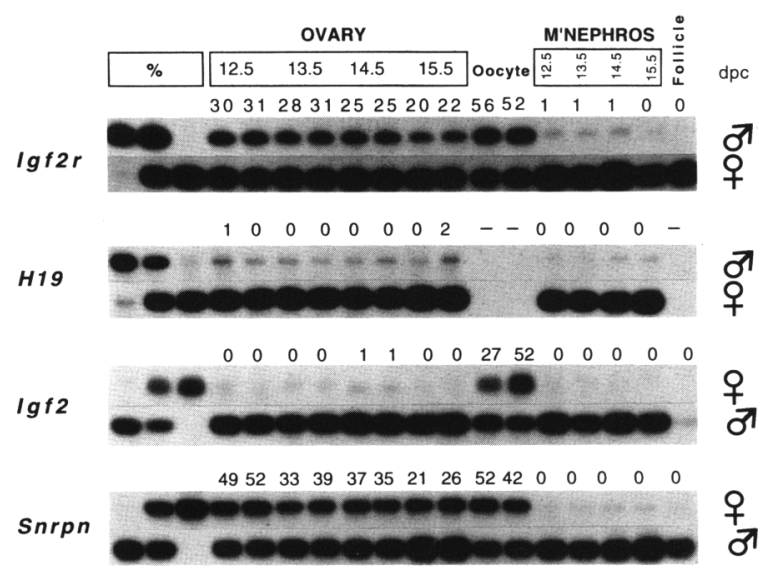

B

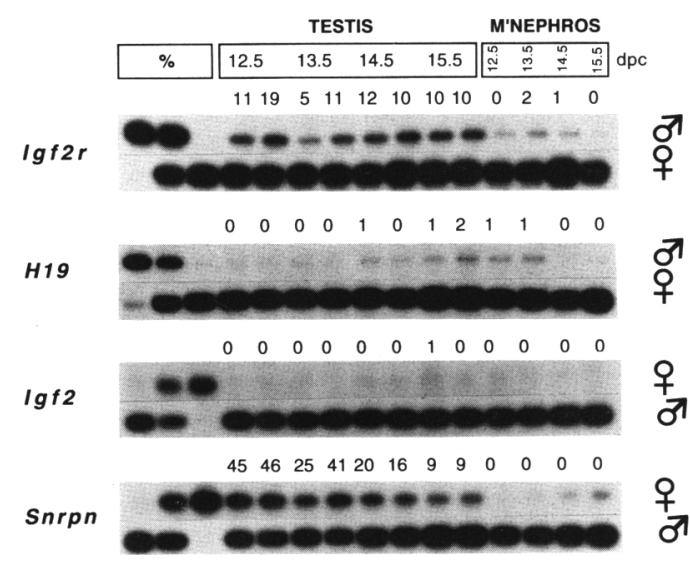

Figure 3. Allele-specific expression of imprinted genes in sexually dimorphic 12.5 to $15.5 \mathrm{dpc}$ embryonic gonads. $(A)$ Ovary and adjacent meso/metanephros (m'nephros). Also shown are ovulated unfertilized oocytes and follicle cells isolated from superovulated adult B6CSF 1 females. RT-PCR was performed on one-fifth of the total RNA obtained from each gonad and m'nephros, and from 10 zona-free oocytes. No H19 RNA was detected in oocytes and follicle cells, and very little Igf2 RNA was detected in follicle cells. The negative signal for $H 19$ was also obtained using groups of 50 oocytes (data not shown). (B) Testis and adjacent $\mathrm{m}^{\prime}$ nephros. Other details are as described in the legend to Fig. 2. 
component. This would also be true on an RNA per cell basis, as the total number of germ cells is similar to the number of Sertoli cells at these stages (Bellvé 1993). The results of the whole study described above are summarized in Figure 5.

A

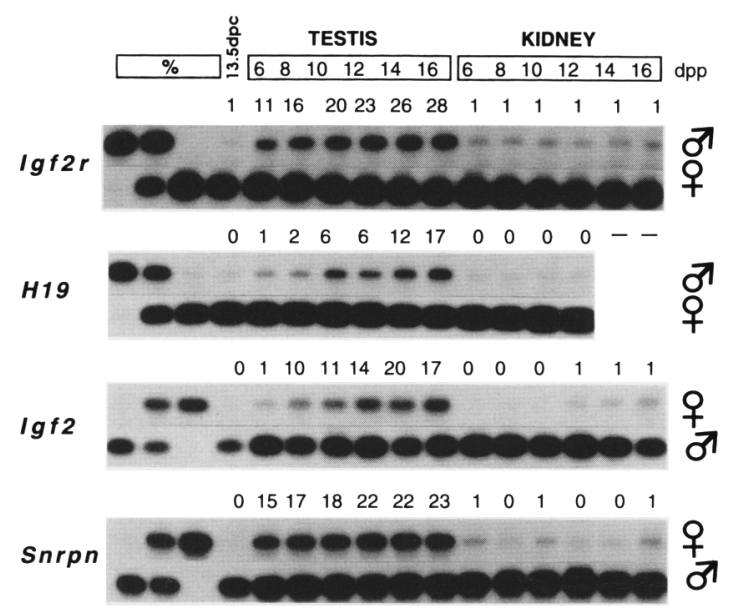

B

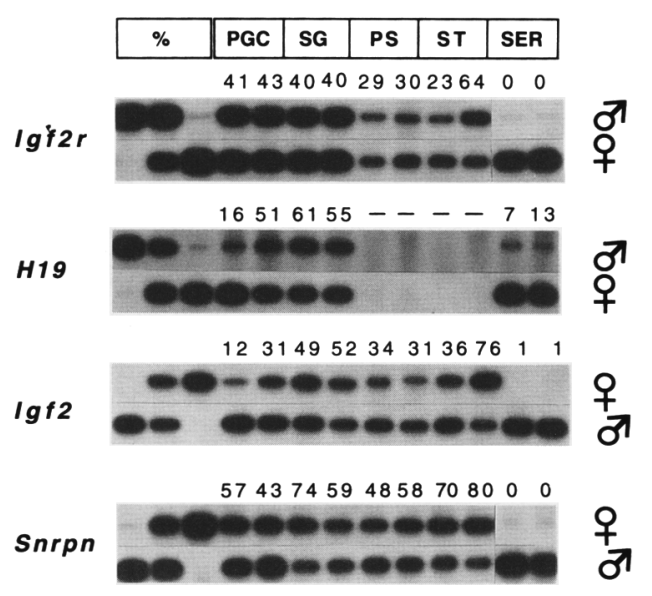

Figure 4. Allele-specific expression in neonatal testis and spermatogenic cells. $(A)$ Neonatal testes: Analyses were conducted on $20 \mathrm{ng}$ of total RNA isolated from one whole testis and kidney of one $\mathrm{B}^{6} \mathrm{CSF}_{1}$ individual for each stage. All six individuals used were littermates. Other details are as described in the legend to Fig. 2, except that the fourth lane is a control, using $100 \mathrm{ng}$ total RNA isolated from the whole $13.5 \mathrm{dpc} \mathrm{B} \mathrm{CSF}_{1}$ embryo minus the head. (B) Spermatogenic and Sertoli cells: (SG) $7.5 \mathrm{dpp}$ mitotic spermatogonia, (PS) adult meiotic pachytene spermatocytes (ST) adult postmeiotic haploid round spermatids (SER) 7.5 dpp Sertoli cells. (PGC) PGCs isolated from sexually indifferent $11.5 \mathrm{dpc}$ gonads shown for comparison (these lanes are also shown in Fig. 2). RT-PCR SNuPE was performed on groups of 100 spermatogenic or Sertoli cells purified to homogeneity by micromanipulation (see Materials and methods). The negative signal for $\mathrm{H} 19$ in PS and ST was also obtained using groups of 300-500 cells (data not shown).

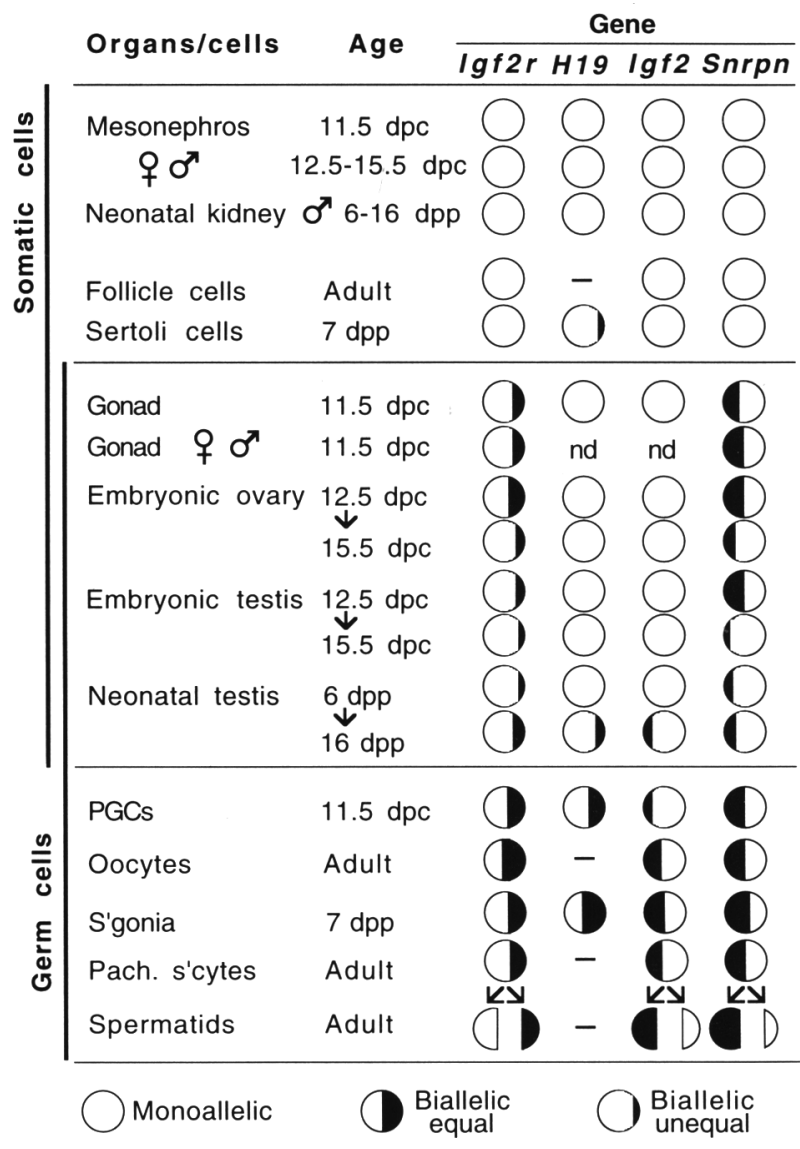

Figure 5. Summary of allele-specific expression of imprinted genes in the germ line and soma. Total circle area represents $100 \%$ expression, contributed by both alleles. The area of the shaded portion represents that proportion coming from the allele normally inactive in the soma. If this is the maternal or paternal allele, the shading is on the left or right, respectively. For spermatids, split circles represent their haploid status.

\section{Expression may be monoallelic in premigratory PGCs at the base of the allantois}

It is not possible manually to purify premigratory PGCs because of their small numbers and because they do not reside in a very discrete structure such as the genital ridge. Nevertheless, as determined by alkaline phosphatase staining, $\sim 125$ are congregated at the base of the allantois of $7.5 \mathrm{dpc}$ late gastrulation presomite-stage embryos (Ginsburg et al. 1990). We therefore compared the allele-specific expression of the four genes in the base and tip of the allantois, the latter of which is devoid of germ cells. The allantoic base section dissected was approximately spherical and $160 \mu \mathrm{m}$ in diameter. Thus, assuming an average cell diameter of $10 \mu \mathrm{m}$, the total number of cells is 4000, placing the proportion of PGCs in this dissected portion crudely at $3 \%$. The SNuPE assays can distinguish a $1 \%$ proportion of expression (Fig. 1); thus, if expression of the four genes in PGCs in this region was biallelic, and at similar or greater than somatic levels, this might be detectable. For Igf2r and Igf2, 
no difference between the tip and the base of the allantois in the bias of allele-specific expression was discerned. In addition, the relative expression level of the least active allele was variable between components of the conceptus (Fig. 6). For H19, less bias in allele-specific expression was observed in the base compared to the tip of the allantois, consistent with the possibility that PGCs might biallelically express this gene. However, although the allantoic tip may be the best reference for the allantoic base, the degree of bias observed in the latter was also seen in the adjacent posterior portion of the embryo (Fig. 6), reducing the significance of this finding. Probably the best indication is provided by the allelespecific expression of Snrpn, for which inactivity of the maternal allele was observed in all components. Therefore, this gene appears to be monoallelically expressed in premigratory PGCs. We have also observed monoallelic expression of Snrpn in the primitive ectoderm at $6.5 \mathrm{dpc}$ (P.E. Szabó and J.R. Mann, unpubl.). This is the germ layer from which PGCs are derived (McLaren 1983; Gardner 1985; Lawson and Hage 1994).

\section{Discussion}

This first study of the allele-specific expression of imprinted genes in the germ line provides a number of implications:

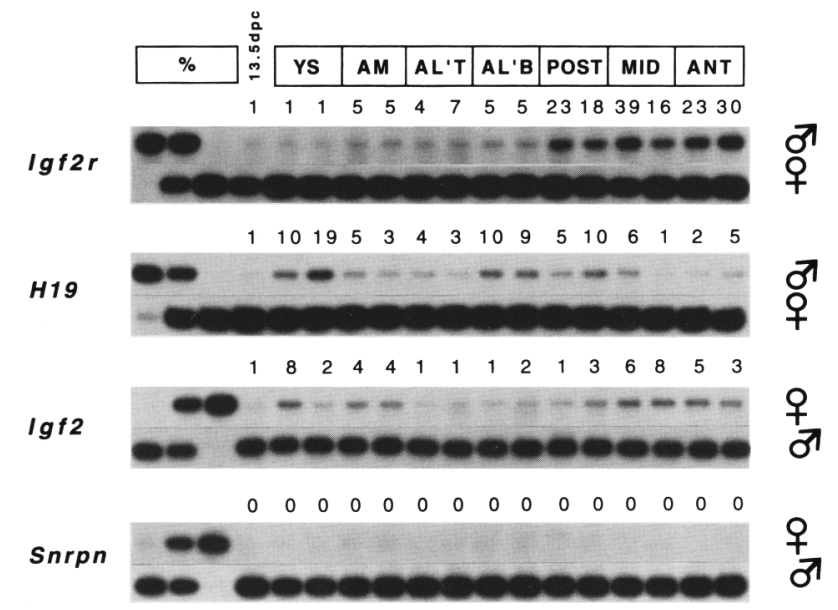

Figure 6. Allele-specific expression in sections of $7.5 \mathrm{dpc}$ embryos. Extraembryonic mesoderm: (AL'T) Tip of allantois; (AL'B) base of allantois (contains premigratory PGCs). Embryonic regions: (POST) posterior (immediately adjacent the allantoic base); (MID) middle (posterior to the node, with most of the primitive streak); (ANT) anterior (neural plate and head process). These sections comprised most of the embryo and were dissected free of the extraembryonic components: (YS) yolk sac; and (AM) amnion. Under each heading, the two lanes represent two individual $\mathrm{B} \mathrm{CSF}_{1}$ embryos. Shown are the results obtained with embryos derived from asynchronous transfer of blastocysts to the uterus after culture for $24 \mathrm{hr}$ from the morula stage. Essentially the same results for each gene were obtained with embryos derived from synchronous transfer of zygotes to oviducts (data not shown). Other details are as described in the legends to Figs. 2 and 4.

\section{Erasure of inherited imprints}

The biallelic expression of all four genes in mitotic postmigratory PGCs of the sexually indifferent genital ridge implies that this mode of expression is a general feature of genes that display a monoallelic mode of expression in the soma, and suggests, as one possibility, a widespread erasure of inherited imprinting in germ cells by this stage of their development. The mode of expression in earlier stage premigratory PGCs requires elucidation, possibly utilizing a method that can sort premigratory PGCs, or by an in situ technique. However, based on the observation of monoallelic expression of Snrpn at the base of the allantois in this study, and in the primitive ectoderm at $6.5 \mathrm{dpc}$ (P.E. Szabó and J.R. Mann, unpubl.), it is likely that the expression of this gene is monoallelic in premigratory PGCs. Thus, a transition to a biallelic mode may occur during their migration to, or arrival at, the genital ridge. If the transition occurs as late as genital ridge colonization, then as suggested for $\mathrm{X}$ chromosome reactivation in XX embryos, germ-line activation of repressed alleles could be in response either to signals from the genital ridge (Tam et al. 1994) or to an inherent temporal mechanism. It may therefore accompany the general change in phenotype acquired by PGCs upon genital ridge colonization (Donovan et al. 1986).

\section{Establishment of new imprints}

Evidence for imprinting establishment would have been provided by oogenic active/spermatogenic inactive expression, or the reciprocal, of imprinted genes according to each gene's parental specific activity in the soma. However, for all genes, the sexually indifferent biallelic expression observed in PGCs persisted throughout germ cell development. Igf2, Snrpn, and Igf2r were biallelically active in both oocytes and spermatogenic cells, and oppositely, H19 RNA was not detected in either oocytes or spermatocytes and spermatids. The latter gene is maternally active in the soma; hence, the lack of detectable H19 RNA in oocytes indicates a lack of potential for expression of this gene, regardless of imprinting status. Cell type-specific inactivity may also explain the lack of detectable $H 19$ RNA in spermatocytes or, alternatively, it could be a function of imprinting of $H 19$ by this stage of spermatogenesis. In turn, imprinting of $H 19$ would result in the activity of $I g f 2$ in spermatocytes: In somatic tissues, Igf2 activity is a function of $H 19$ inactivity as determined by imprinting of the latter gene (Leighton et al. 1995). However, this alternative explanation must take into account the fact that the inactivity of $H 19$ in oocytes cannot be determined by imprinting, yet Igf 2 is also active in these cells: Given the cell-specific inactivity of $H 19$, Igf2 would also be expected to be inactive, as these genes show similar tissue-specific patterns of expression during development (Lee et al. 1990; Poirier et al. 1991).

One explanation of the general findings is that sexspecific imprints are not established until late in gametogenesis. How late this might occur is uncertain: In 
oocytes, it is unknown if the "inappropriate" expression of Snrpn and Igf2 (matemally inactive in the soma) represents that occurring during the oocyte growth phase or during the later maturation phases. Many RNA species produced during oocyte growth are stored and dormant (Huarte et al. 1987). Similarly, in groups of haploid round spermatids, existent RNA of $\lg f 2 r$ (paternally inactive in the soma) could have represented that expressed at earlier spermatogenic stages, or at this early haploid stage. The fact that mice can be produced by the fusion of a haploid round spermatid with an ovulated oocyte strongly suggests that paternal imprinting is complete by this stage of spermatogenesis (Ogura et al. 1994). Nevertheless, although there is little evidence for regionalized differentiation of the egg cytoplasm, there remains the formal possibility that the maternal and paternal genomes may thereby be differentially modified, with initial or primary imprints being imparted after introduction of the paternal nucleus into the egg cytoplasm.

The chromatin structures of the maternal and paternal pronuclei are not identical, and it has been suggested that consequent differential accessibility of transcription factors and methylation enzymes could lead to the imprinting of genes (Wiekowski et al. 1993). However, in this case, differences in maternal and paternal pronuclear chromatin structure could be thought of as one of a series of imprinting events that could eventually lead to monoallelic expression; that is, rather than being a onetime event late in gametogenesis or in the zygote, imprinting may be a multistep process such that prezygotic, then sequential zygotic and postzygotic epigenetic events occur in cis before monoallelic expression is established (Allen and Mooslehner 1992; Chaillet 1992; Bartolomei et al. 1993; Brandeis et al. 1993; FergusonSmith et al. 1993; Feil et al. 1994; Latham et al. 1994; Szabó and Mann 1994).

\section{Bypass of imprinting}

Whereas absence of imprinting, or incomplete imprinting, may explain the biallelic and sexually indifferent expression of imprinted genes in the germ line, an alternative explanation is that fully established inherited and/or new imprints are not recognized or bypassed. It is of interest that pluripotent cell lines isolated from PGCs of the male $12.5 \mathrm{dpc}$ genital ridge can invoke skeletal defects in chimeras reminiscent of those specific to androgenetic chimeras (Mann et al. 1990; Labosky et al. 1994). Although this might be indicative of an early establishment of paternal imprints, it is not known whether the two phenotypes have the same etiology and whether pluripotent cell lines isolated from female genital ridges might also invoke the abnormalities.

If imprinting is bypassed in the germ line, how might this be achieved? Bypass of imprinting has been suggested as a mechanism in explanation of the biallelic expression of imprinted genes during preimplantation development, embryonic stem (ES) cells, exceptional tissues, and tumors (Barlow 1994; Efstratiadis 1994; Latham et al. 1994; Szabó and Mann 1994). More specif- ically, trans-acting factors, which interact with imprints in a stage- and cell-specific manner to activate or inactivate alleles, have been invoked to explain transitions from biallelic to monoallelic modes of expression, and vice versa (Barlow et al. 1994; Latham et al. 1994). For the germ line, an alternative model based on chromatin structure is also possible: Experiments involving the injection of promoter-enhancer constructs into ova have indicated that enhancers act by relieving repression of promoters. Moreover, alteration of chromatin structure in the zygote can result in bypass of this enhancer-dependent promoter activity (Majumder et al. 1993; Wiekowski et al. 1993). Thus, if imprinting were to act by blocking enhancer function, thereby causing a gene to remain inactive in cis, this function could be bypassed in the germ line by some generalized alteration in chromatin structure. This model is depicted in Figure 7. In this model, alterations in chromatin structure, specific to germ cells, allows promoter activity regardless of the status of enhancer functionality. This model accounts for the biallelic expression in both the female and male germ lines of all four imprinted genes examined. More specifically, it readily accounts for the biallelic coexpression of $H 19$ and Igf2 in PGCs and spermatogonia, as in

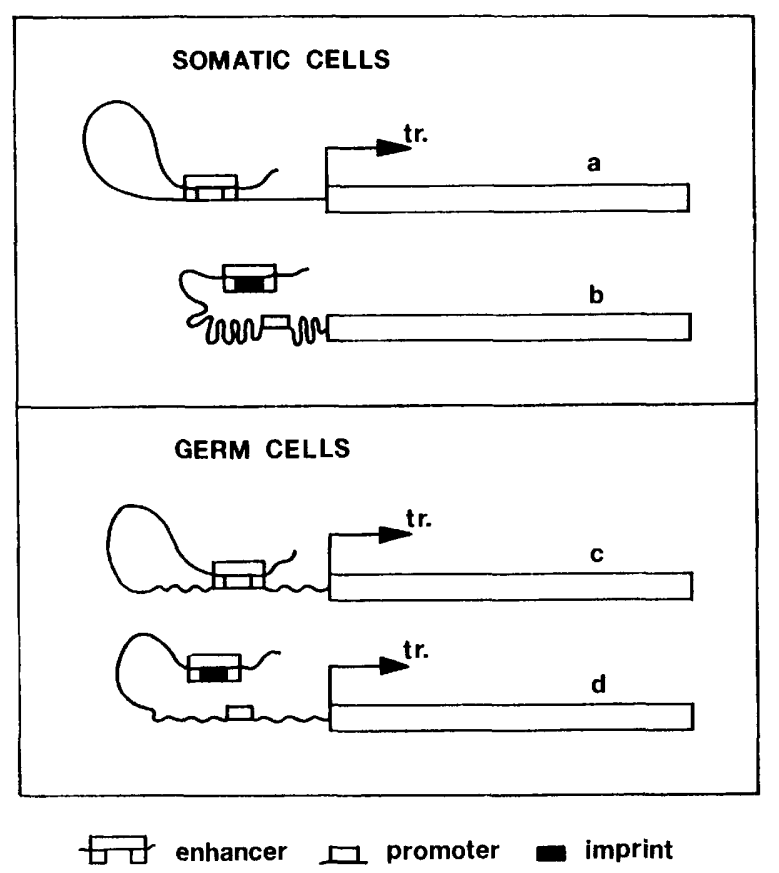

Figure 7. Enhancer imprinting model. Somatic cells: $|a|$ Transcription is allowed by the chromatin structure that results from the interaction between the enhancer and the promoter. (b) Transcription is disallowed by a constrained chromatin structure, e.g., in the $5^{\prime}$ region, as the imprint, e.g., CpG methylation, blocks interaction between the enhancer and the promoter. Germ cells: $(c, d)$ a unique chromatin conformation is conducive to promoter activity, irrespective of the status of interaction between the enhancer and the promoter. In these cells, levels of expression would not be expected to be as high as in somatic cells that fully utilize the enhancers. 
somatic tissues, mutually exclusive expression of $H 19$ and Igf2 in cis is enhancer dependent (Bartolomei et al. 1993; Leighton et al. 1995).

How might the alteration in chromatin structure suggested in the model be achieved? Hyperacetylation of core histones is known to alter chromatin structure, and transcriptionally active chromatin is hyperacetylated (Turner 1991; Jeppesen and Turner 1993). Cytosine methylation can influence chromatin structure (Zacharias 1993). In addition, the presence of methylation at specific sites, such as promoters and CpG islands on the $\mathrm{X}$ chromosome, can be associated with gene repression (for review, see Jost and Saluz 1993). Also, Xenopus germ cells possess at least one unique histone variant (Chao and Wolffe 1994; Dworkin-Rastl et al. 1994). Although the histone acetylation status of germ cells is unknown, PGCs of the $12.5 \mathrm{dpc}$ gonad are known to be globally undermethylated (Monk et al. 1987; Kafri et al. 1992), which could contribute to a relaxation of constraints in chromatin structure. These considerations of imprinting bypass could be relevant to the biallelic expression of imprinted genes in methylation-deficient mouse embryos (Li et al. 1993). In this instance, rather than the loss of imprints being the primary event, generalized alterations in chromatin structure, caused by methylation deficiency, may lead to the bypass of fully imprinted regulatory elements.

\section{Germ cell development}

Although the status of imprinting in the germ line will be facilitated by the unequivocal identification of an imprinting mechanism, our results demonstrate that from the time PGCs enter the genital ridge, and possibly earlier, the germ line has no requirement for genomic imprinting in terms of monoallelic expression, that is, if the function of imprinting is to invoke monoallelic expression, then this function is neutralized in the germ line. One possible reason for this neutralization may be to retain the potential for the activity of those imprinted genes that would otherwise exhibit a $-/$ - mode of expression. However, on this point, both sexes of mice with no Igf2 or H19 activity are fully fertile (DeChiara et al. 1991; Leighton et al. 1995). The findings also imply that there is no functional difference between the inherited maternal and paternal genomes in germ cell development, at least by the time of genital ridge colonization. A logical extension of this implication is that PGCs of parthenogenetic and androgenetic origin may have the same potential as wild-type PGCs for normal development and differentiation in either sexual pathway.

Imprinting neutralization would appear to be a salient feature of the germ line and is coincident with the unique developmental potentiality of this cell lineage. It has been suggested that a restoration of totipotency in germ cells, subsequent to prior restrictive events in their primitive ectoderm cell progenitors, is linked with the onset of meiosis, $\mathrm{X}$ chromosome reactivation, and erasure of imprinting (Monk 1981, 1988). However, if there is a linkage between imprinting neutralization and nu- clear totipotency in the germ line, then the restoration of totipotency must occur sometime during the mitotic phase of germ cell development, and before sexual differentiation of the gonad.

\section{Materials and methods}

\section{Quantitative RT-PCR SNuPE assays}

These assays were performed essentially as described (SingerSam et al. 1992).

Preparation of RNA Tissue samples were collected in $0.1 \mathrm{ml}$ of RNAzol (Tel-Test Inc., Friendswood, TX). To facilitate precipitation of RNA, $2 \mu \mathrm{l}$ of $0.25 \%$ linear polyacrylamide was added as carrier (Gaillard and Strauss 1990). The pellet was dissolved in water containing $1 \mathrm{U} / \mu \mathrm{l}$ of RNasin (Promega) and 10 $\mathrm{mM}$ DTT, which were carried over in the RT-PCR reaction.

$R T-P C R$ All reactions were carried out in a Programmable Thermal Controller (MJ Research Inc., Watertown, MA). RNA was preassociated with $2.5 \mu \mathrm{M}$ of the lower primer, in $10 \mathrm{mM}$ Tris- $\mathrm{HCl}$ at $\mathrm{pH} 8.3,50 \mathrm{~mm} \mathrm{KCl}, 5 \mathrm{~mm} \mathrm{MgCl}$, and $1 \mathrm{~mm}$ dNTPs by incubating at $64^{\circ} \mathrm{C}$ for $10 \mathrm{~min}$ and then slowly cooling to $42^{\circ} \mathrm{C}$ for $15 \mathrm{~min}$. At this point, $2.5 \mathrm{U} / \mu \mathrm{l}$ of Moloney murine leukemia virus reverse transcriptase (GIBCO-BRL) and $1 \mathrm{U} / \mu \mathrm{l}$ of RNasin was added, and the incubation continued at $42^{\circ} \mathrm{C}$ for $15 \mathrm{~min}$. The RT reaction was stopped by heating to $99^{\circ} \mathrm{C}$ for 5 min. Samples were then cooled to $65^{\circ} \mathrm{C}$ and kept at this temperature while being pipetted into tubes containing PCR master mix, and then the PCR reaction was started. The final concentrations of ingredients in $0.1-\mathrm{ml}$ PCR reactions were $10 \mathrm{~mm}$ Tris- $\mathrm{HCl}$ at $\mathrm{pH} 8.3,50 \mathrm{mM} \mathrm{KCl}, 1 \mathrm{mM} \mathrm{MgCl} 2,200 \mu \mathrm{M}$ dNTPs, $0.5 \mu \mathrm{M}$ of the lower and upper primers and 2.5 units per reaction of AmpliTaq DNA polymerase (Perkin-Elmer Cetus). PCR run conditions were $95^{\circ} \mathrm{C}$ for $30 \mathrm{sec}, 42^{\circ} \mathrm{C}$ for $30 \mathrm{sec}$, and $72^{\circ} \mathrm{C}$ for 2 min for 40 cycles. PCR primers had a $T_{m}$ of $52-64^{\circ} \mathrm{C}$ at $2 \mathrm{~mm}$ $\mathrm{MgCl}_{2}$, and were designed with the aid of a computer program (Oligo 4.0, National Bioscience Inc., Plymouth MN). Isolation of amplified DNA products: These were subjected to agarose gel electrophoresis in $1 \times$ TAE buffer, and the single bands obtained were isolated with the Prep-A-Gene DNA Purification Kit (BioRad). DNA was suspended in water at $\sim 2 \mathrm{ng} / \mu \mathrm{l}$.

SNUPE The reaction mix contained, in a total volume of $10 \mu \mathrm{l}$, $\sim 10 \mathrm{ng}$ of the isolated DNA fragment, $1 \mu \mathrm{M}$ of the SNuPE primer, $10 \mathrm{~mm}$ Tris- $\mathrm{HCl}$ at $\mathrm{pH} 8.3,50 \mathrm{mM} \mathrm{KCl}, 2 \mathrm{~mm} \mathrm{MgCl}_{2}$, 0.75 units of AmpliTaq DNA polymerase, and $2 \mu \mathrm{Ci}$ of $\left[{ }^{32} \mathrm{P}\right] \mathrm{dNTP}$ according to Table 1 . The radionucleotides $[3000 \mathrm{Ci} /$ mmole, $10 \mu \mathrm{Ci} / \mathrm{ml}$, were diluted 10 -fold in water, and $2-\mu \mathrm{l}$ aliquots were added to each tube just prior to incubation. All other ingredients were added to the template as a master mix. Primers were kept in small aliquots to avoid repeated freezethawing. The SNuPE reaction consisted of one cycle of $95^{\circ} \mathrm{C}$ for $30 \mathrm{sec}, 42^{\circ} \mathrm{C}$ for $30 \mathrm{sec}$, and $72^{\circ} \mathrm{C}$ for $1 \mathrm{~min}$. After electrophoresis of the samples on a $15 \%$ denaturing polyacrylamide gel, bands were visualized by autoradiography and quantified with a PhosphorImager (Molecular Dynamics, Sunnyvale, CA).

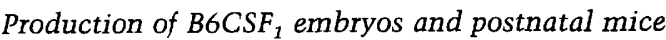

Prepubertal B6 female mice (Jackson Laboratory, Bar Harbor, ME) were superovulated by injection of pregnant mare's serum gonadotrophin and human chorionic gonadotrophin (HCG) (Hogan et al. 1994) and caged with CS males (Jackson Labora- 
tory) for mating. The resulting $\mathrm{B} \mathrm{CSF}_{1}$ zygotes were released from oviducts in medium M2 (Wood et al. 1987) and transferred immediately to oviducts of $0.5 \mathrm{dpc}$ pseudopregnant recipients; or $\mathrm{B}_{6 \mathrm{CSF}} \mathrm{m}_{1}$ morulae were flushed from oviducts at $2.5 \mathrm{dpc}$, cultured overnight in medium CZB plus glucose /Chatot et al. 1989 ) to the blastocyst stage, and transferred to the uteri of 2.5 dpc pseudopregnant recipients according to Mann (1993), except that the following anesthetic regime was used: Mice were injected with $19 \mu \mathrm{g}$ of fentanyl citrate (Elkins-Sinn Inc., Cherry Hill, NJ) and $113 \mu \mathrm{g}$ of midazolam $\mathrm{HCl}$ (Versed; Roche Pharma. Inc., Minati, PR) together in $0.5 \mathrm{ml}$ into the body cavity and, after $3 \mathrm{~min}$, were fully anesthetized with a nose cone $13-\mathrm{ml}$ disposable hypodermic syringe cover) containing gauze soaked with methoxyflurane (Metofane, Pitman-Moore Inc., Mundelein, IL), which was removed after commencement of surgery. Following surgery, and before administering a wound-clip, $2 \mu \mathrm{g}$ of naloxone $\mathrm{HCl}$ (Astra Pharma. Prod. Inc., Westborough, MA) in $50 \mu \mathrm{l}$ was pipetted into the body cavity to reverse the effects of fentanyl; after Flecknell (1993).

\section{Purification of germ and somatic cells}

Oocytes and follicle cells Adult $\mathrm{B} 6 \mathrm{CSF}_{1}$ females were injected with superovulatory hormones as described above, and $14 \mathrm{hr}$ after HCG injection, the oviducts were removed and the masses of unfertilized oocytes and adhering follicle cells were released into medium M2 containing hyaluronidase. Following release of the oocytes from follicle cells, they were rinsed repeatedly in successive changes of medium M2 until all follicle cells were absent; the zonae pellucidae were then removed by acid Tyrode's treatment (Hogan et al. 1994). Small groups of oocytes or much larger numbers of follicle cells were then pipetted into $0.1-\mathrm{ml}$ aliquots of RNAzol in microcentrifuge tubes and kept frozen over liquid nitrogen until SNuPE analysis.

Spermatogenic and Sertoli cells Seminiferous tubules were dispersed into a single cell suspension according to Bellvé (1993), except that the base medium used throughout was PB1 (Wood et al. 1987) minus pyruvate, plus nonessential amino acids and glutamine at standard concentrations. For purification, two shallow drops of medium were placed onto the undersurface of a $6-\mathrm{cm}$ tissue culture dish lid and overlaid with paraffin oil, and some of the suspension of spermatogenic cells pipetted into one of the drops. Then, under phase-contrast optics, cells of a particular identity were recognized according to size (Bellvé 1993), aspirated into a glass collection pipette controlled by a micrometer syringe [similar to that used in ES cell blastocyst injection, Hogan et al. (1994)], and expelled into the second drop of medium as discrete groups of 100 cells. This procedure for purification was used instead of the gravity sedimentation method (Bellvé 1993) so as to obtain samples as close to absolute purity as possible for RT-PCR. Each group of cells was placed into RNAzol and stored as described above until SNuPE analysis. Pachytene spermatocytes and round spermatids were collected from adult $\mathrm{B} \mathrm{CSF}_{1}$ testes, and spermatogonia and Sertoli cells were collected from $7.0 \mathrm{dpp} \mathrm{B6CSF}$, testes.

PGCs These cells from $11.5 \mathrm{dpc}$ genital ridges were dispersed according to Buehr and McLaren (1993). Then, groups of 100 PGCs were collected by micromanipulation, placed into RNAzol, and stored as described above for spermatogenic cells.

\section{Acknowledgments}

We thank Gerd Pfeifer for inspiration and advice, Jeanne LeBon and Judy Singer-Sam for technical advice, Hector Rivera for DNA sequencing of subclones, Gerd Pfeifer, Ibolya Kiss, Art Riggs, and Judy Singer-Sam for their comments on the manuscript, and Peter Rotwein for providing $\operatorname{Igf} 2 r$ sequence information. This work was supported by a National Institutes of Health award (MGN 1R01 GM48103-01) and a National Science Foundation award (MCB 9405373) to J.R.M.

The publication costs of this article were defrayed in part by payment of page charges. This article must therefore be hereby marked "advertisement" in accordance with 18 USC section 1734 solely to indicate this fact.

\section{References}

Allen, N.D. and K.A. Mooslehner. 1992. Imprinting, transgene methylation and genotype-specific modification. Sem. Dev. Biol. 3: 87-98.

Allen, N.D., S.C. Barton, K. Hilton, M.L. Norris, and M.A. Surani. 1994. A functional analysis of imprinting in parthenogenetic embryonic stem cells. Development 120: 14731482.

Barlow, D.P. 1994. Imprinting: A gamete's point of view. Trends Genet. 10: 194-199.

Barlow, D.P., R. Stöger, B.G. Herrmann, K. Saito, and N. Schweifer. 1991. The mouse insulin-like growth factor type-2 receptor is imprinted and closely linked to the Tme locus. Nature 349: 84-87.

Bartolomei, M.S., S. Zemel, and S.M. Tilghman. 1991. Parental imprinting of the mouse $H 19$ gene. Nature 351: 153-155.

Bartolomei, M.S., A.L. Webber, M.E. Brunkow, and S.M. Tilghman. 1993. Epigenetic mechanisms underlying the imprinting of the mouse H19 gene. Genes \& Dev. 7: 1663-1673.

Beechey, C.V. and B.M. Cattanach. 1995. Genetic imprinting map. Mouse Genome 93: 89-92.

Bellvé, A.R. 1993. Purification, culture, and fractionation of spermatogenic cells. Guide to techniques in mouse development. Methods Enzymol. 225: 84-113.

Brandeis, C.V., T. Kafri, M. Ariel, J.R. Chaillet, J.R. McCarrey, A. Razin, and H. Cedar. 1993. The ontogeny of allele-specific methylation associated with imprinted genes in the mouse. EMBO I. 12: 3669-3677.

Buehr, M. and A. McLaren. 1993. Isolation and culture of mouse primordial germ cells. Guide to techniques in mouse development. Methods Enzymol. 225: 58-87.

Buzin, C.H., J.R. Mann, and J. Singer-Sam. 1994. Quantitative RT-PCR assays show Xist RNA levels are low in mouse female adult tissue and embryoid bodies. Development 120: 3529-3536.

Cattanach, B.M. and M. Kirk. 1985. Differential activity of maternally and paternally derived chromosome region in mice. Nature 315: 496-498.

Cattanach, B.M., J.A. Barr, E.P. Evans, M. Burtenshaw, C.V. Beechey, S.E. Leff, C.I. Brannan, N.G. Copeland, N.A. Jenkins, and J. Jones. 1992. A candidate mouse model for PraderWilli syndrome which shows an absence of Snrpn expression. Nature Genet. 2: 270-274.

Chaillet, J.R. 1992. DNA methylation and genomic imprinting in the mouse. Sem. Dev. Biol. 3: 99-105.

Chao, H. and A.P. Wolffe. 1994. Xenopus laevis B4, an introncontaining oocyte-specific linker histone-encoding protein. Gene 143: 233-238.

Chatot, C.L., C.A. Ziomek, B.D. Bavister, J.L. Lewis, and I. 
Torres. 1989. An improved medium supports development of random-bred 1-cell mouse embryos in vitro. $)$. Reprod. Fert. 86: 679-688.

DeChiara, T.M., E.J. Robertson, and A. Efstratiadis. 1991. Parental imprinting of the mouse insulin-like growth factor II gene. Cell 64: 849-859.

Donovan, P.J., D. Stott, L.A. Cairns, J. Heasman, and C.C. Wylie. 1986. Migratory and postmigratory mouse primordial germ cells behave differently in culture. Cell 44: 831-838.

Dworkin-Rastl, E., H. Kandolf, and R.C. Smith. 1994. The maternal histone $\mathrm{H} 1$ variant, $\mathrm{H} 1 \mathrm{M}$ (B4 protein), is the predominant $\mathrm{H} 1$ histone in Xenopus pregastrula embryos. Dev. Biol. 161: 425-439.

Eddy, E.M., J.M. Clark, D. Gong, and B.A. Fenderson. 1981. Origin and migration of primordial germ cells in mammals. Gamete Res. 4: 333-362.

Efstratiadis, A. 1994. Parental imprinting of autosomal mammalian genes. Curr. Opin. Genet. Dev. 4: 265-280.

Feil, R., J. Walter, N.D. Allen, and W. Reik. 1994. Developmental control of allelic methylation in the imprinted mouse Igf2 and H19 genes. Development 129: 2933-2943.

Ferguson-Smith, A.C., B.M. Cattanach, S.C. Barton, C.V. Beechey, and M.A. Surani. 1991. Embryological and molecular investigations of parental imprinting on mouse chromosome 7. Nature 351: 667-670.

Ferguson-Smith, A.C., H. Sasaki, B.M. Cattanach, and M.A. Surani. 1993. Parental-origin-specific modification of the mouse $H 19$ gene. Nature 362: 751-747.

Flecknell, P.A. 1993. Anesthesia and perioperative care. Guide to techniques in mouse development. Methods Enzymol. 225: 16-33.

Gaillard, C. and F. Strauss. 1990. Ethanol precipitation of DNA with linear polyacrylamide as a carrier. Nucleic Acids Res. 18: 378 .

Gardner, R.L. 1985. Clonal analysis of early mammalian development. Phil. Trans. R. Soc. Lond. B. 312: 163-178.

Gerrelli, D., N.G. Sharpe, and D.S. Latchman. 1991. Cloning and sequencing of a mouse embryonal carcinoma cell mRNA encoding the tissue specific RNA splicing protein SmN. Nucleic Acids Res. 19: 6642.

Ginsburg, M., M.H.L. Snow, and A. McLaren. 1990. Primordial germ cells in the mouse embryo during gastrulation. Development 110: 521-528.

Gomperts, M., M. Garcia-Castro, C. Wylie, and J. Heasman. 1994. Interactions between germ cells play a role in their migration in mouse embryos. Development 120: 135-141.

Guillemot, F., A. Nagy, A. Auerbach, J. Rossant, and A.L. Joyner. 1994. Essential role of Mash-2 in extraembryonic development. Nature 371: 333-336.

Guillemot, F., T. Caspary, S.M. Tilghman, N.G. Copeland, D.J. Gilbert, N.A. Jenkins, D.J. Anderson, A.L. Joyner, J. Rossant, and A. Nagy. 1995. Genomic imprinting of Mash2, a mouse gene required for trophoblast development. Nature Genet. 9: 235-241.

Hogan, B., R. Beddington, F. Costantini, and E. Lacy. 1994. Manipulating the mouse embryo, 2nd ed. Cold Spring Harbor Laboratory Press, Cold Spring Harbor, New York..

Huarte, J., D. Belin, A. Vassalli, S. Strickland, and J.-D. Vassalli. 1987. Meiotic maturation of mouse oocytes triggers the translation and polyadenylation of dormant tissue-type plasminogen activator mRNA. Genes \& Dev. 1: 1201-1211.

Jeppesen, P. and B.M. Turner. 1993. The inactive X chromosome in female mammals is distinguished by a lack of histone $\mathrm{H} 4$ acetylation, a cytogenetic marker for gene expression. Cell 74: 281-289.

Jost, P. and H.P. Saluz. 1993. DNA methylation: Molecular bi- ology and biological significance. Birkhäuser Verlag, Basel, Switzerland.

Kafri, T., M. Ariel, M. Brandeis, R. Shemer, L. Urven, J. McCarrey, H. Cedar, and A. Razin. 1992. Developmental pattern of gene-specific DNA methylation in the mouse embryo and germ line. Genes \& Dev. 6: 705-714.

Kaufman, M.H., K.K.H. Lee, and S. Speirs. 1989. Post-implantation development and cytogenetic analysis of diandric heterozygous diploid mouse embryos. Cytogenet. Cell Genet. 52: 15-18.

Labosky, P.A., D.P. Barlow, and B.L.M. Hogan. 1994. Mouse embryonic germ (EG) cell lines: Transmission through the germline and differences in the methylation imprint of insulin-like growth factor 2 receptor (Igf2r) gene compared with embryonic stem (ES) cell lines. Development 120: 3197-3204.

Latham, K.E., A.S. Doherty, C.D. Scott, and R.M. Schultz. 1994. $I g f 2 r$ and $I g f 2$ gene expression in androgenetic, gynogenetic, and parthenogenetic preimplantation mouse embryos: $\mathrm{Ab}-$ sence of regulation by genomic imprinting. Genes \& Dev. 8: 290-299.

Lau, M.M.H., C.E.H. Stewart, Z. Liu, H. Bhatt, P. Rotwein, and C.L. Stewart. 1994. Loss of the imprinted IGF2/cation-independent mannose 6-phosphate receptor results in fetal overgrowth and perinatal lethality. Genes \& Dev. 8: 2953-2963.

Lawson, K.A. and W.J. Hage. 1994. Clonal analysis of the origin of primordial germ cells in the mouse. Germline development. Ciba Found. Symp. 182: 68-91.

Lee, J.E., J. Pintar, and A. Efstratiadis. 1990. Pattern of the insulin-like growth factor II gene expression during early mouse embryogenesis. Development 110: 151-159.

Leff, S.E., C.I. Brannan, M.L. Reed, T. Özcelik, U. Francke, N.G. Copeland, and N.A. Jenkins. 1992. Maternal imprinting of the mouse Snrpn gene and conserved linkage homology with the human Prader-Willi syndrome region. Nature Genet. 2: 259-264.

Leighton, P.A., R.S. Ingram, J. Eggenschwiler, A. Efstratiadis, and S.M. Tilghman. 1995. Disruption of imprinting caused by deletion of the $H 19$ gene region in mice. Nature 375: $34-$ 39.

Li, E., C. Beard, and R. Jaenisch. 1993. Role for DNA methylation in genomic imprinting. Nature 366: 362-365.

Lyon, M.F. and P.H. Glenister. 1977. Factors affecting the observed number of young resulting from adjacent- 2 disjunction in mice carrying a translocation. Genet. Res. Camb. 29: 83-92.

Majumder, S., M. Miranda, and M.L. DePamphilis. 1993. Analysis of gene expression in mouse preimplantation mouse embryos demonstrates that the primary role of enhancers is to relieve repression of promoters. EMBO I. 12: 1131-1140.

Mann, J.R. 1993. Surgical techniques in the production of transgenic mice. Guide to techniques in mouse development. Methods Enzymol. 225: 782-793.

Mann, J.R. and R.H. Lovell-Badge. 1984. Inviability of parthenogenones is determined by pronuclei, not egg cytoplasm. Nature 310: 66-67.

- 1987. The development of XO gynogenetic mouse embryos. Development 99: 411-416.

. 1988. Two maternally derived X chromosomes contribute to parthenogenetic inviability. Development 104: 129136.

Mann, J.R., I. Gadi, M.L. Harbison, S.J. Abbondanzo, and C.L. Stewart. 1990. Androgenetic mouse embryonic stem cells are pluripotent and cause skeletal defects in chimeras. Cell 62: 251-260.

McGrath, J. and D. Solter. 1984. Completion of mouse embryo- 
genesis requires both the maternal and paternal genomes. Cell 37: 179-183.

McLaren, A. 1983. Primordial germ cells in mice. Bibl. Anat. 24: 59-66.

Monk, M. 1981. A stem-line model for cellular and chromosomal differentiation in early mouse development. Differentiation 19: 71-76.

1988. Genomic imprinting. Genes \& Dev. 2: 921-925.

Monk, M., M. Boubelik, and S. Lehnert. 1987. Temporal and regional changes in DNA methylation in the embryonic, extraembryonic and germ cell lineages during mouse embryo development. Development 99: 371-382.

Ogawa, O., M.R. Eccles, J. Szeto, L.A. McNoe, K. Yun, M.A. Maw, P.J. Smith, and A.E. Reeve. 1993. Relaxation of insulin-like growth factor II gene imprinting implicated in Wilm's tumour. Nature 362: 749-751.

Ogura, A., J. Matsuda, and R. Yanagimachi. 1994. Birth of normal young after electrofusion of mouse oocytes with round spermatids. Proc. Natl. Acad. Sci. 91: 7460-7462.

Pachnis, V., C.I. Brannan, and S.M. Tilghman. 1988. The structure and expression of a novel gene activated in early embryogenesis. EMBO J. 7: 673-681.

Poirier, F., C.-T.J. Chan, P.E. Timmons, E.J. Robertson, M.J. Evans, and P.W.J. Rigby. 1991. The murine $H-19$ gene is activated during embryonic stem cell differentiation in vitro and at the time of implantation in the developing embryo. Development 113: 1105-1114.

Rainier, S., L.A. Johnson, C.J. Dobry, A.J. Ping, P.E. Grundy, and A.P. Feinberg. 1993. Relaxation of imprinted genes in human cancer. Nature 362: 747-749.

Rotwein, P. and L.J. Hall. 1990. Evolution of insulin-like growth factor II: Characterization of the mouse IGF-II gene and identification of two pseudo-exons. DNA Cell Biol. 9: 725-735.

Sasaki, H., P.A. Jones, J.R. Chaillet, A.C. Ferguson-Smith, S.C. Barton, W. Reik, and M.A.H. Surani. 1992. Parental imprinting: Potentially active chromatin of the repressed maternal allele of the mouse insulin-like growth factor II (Igf2) gene. Genes \& Dev. 6: 1843-1856.

Singer-Sam, J., M.O. Robinson, A.R. Bellvé, M.I. Simon, and A.D. Riggs. 1990. Measurement by quantitative PCR of changes in HPRT, PGK-1, PGK-2, APRT, MTase, and ZFY gene transcripts during mouse spermatogenesis. Nucleic Acids Res. 18: 1255-1259.

Singer-Sam, J., J.M. LeBon, A. Dai, and A.D. Riggs. 1992. A sensitive, quantitative assay for measurement of allele-specific transcripts differing by a single nucleotide. PCR Methods Appl. 1: 160-163.

Stevens, L.C. 1978. Totipotent cells of parthenogenetic origin in a chimaeric mouse. Nature 276: 266-267.

Surani, M.A.H., S.C. Barton, and M.L. Norris. 1984. Development of reconstituted mouse eggs suggests imprinting of the genome during gametogenesis. Nature 308: 548-550.

Szabó, P. and J.R. Mann. 1994. Expression and methylation of imprinted genes during in vitro differentiation of mouse parthenogenetic and androgenetic embryonic stem cell lines. Development 120: 1651-1660.

Szebenyi, G. and P. Rotwein. 1994. The mouse insulin-like growth factor II/cation-independent mannose 6-phosphate (IGF-II/MPR) receptor gene: Molecular cloning and genomic organization. Genomics 19: 120-129.

Takagi, N., N. Wake, and M. Sasaki. 1978. Cytologic evidence for preferential inactivation of the paternally derived $\mathrm{X}$ chromosome in XX mouse blastocysts. Cytogenet. Cell Genet. 20: $240-248$.

Takagi, N. and K. Abe. 1990. Detrimental effects of two active $\mathrm{X}$ chromosomes on early mouse development. Development
109: 189-201.

Tam, P.P.L. and M.H.L. Snow. 1981. Proliferation and migration of primordial germ cells during compensatory growth in mouse embryos. I. Embryol. Exp. Morphol. 64: 133-147.

Tam, P.P.L., S.X. Zhou, and S-S. Tan. 1994. X-chromosome activity of the mouse primordial germ cells revealed by the expression of an X-linked lacZ transgene. Development 120: $2925-2932$.

Turner, B.M. 1991. Histone acetylation and control of gene expression. I. Cell Sci. 99: 13-20.

Wang, Z.-Q., M.R. Fung, D.P. Barlow, and E.F. Wagner. 1994. Regulation of embryonic growth and lysosomal targeting by the imprinted Igf2/Mpr gene. Nature 372: 464-467.

Wiekowski, M., M. Miranda, and M.L. DePamphilis. 1993. Requirements for promoter activity in mouse oocytes and embryos distinguish paternal pronuclei from maternal and zygotic nuclei. Dev. Biol. 159: 366-378.

Wood, M.J., D.G. Whittingham, and W.F. Rall. 1987. The low temperature preservation of mouse oocytes and embryos. In Mammalian development: A practical approach (ed. M. Monk), pp. 255-280. IRL Press, Oxford, UK.

Zacharias, W. 1993. Methylation of cytosine influences the DNA structure. In DNA methylation: Molecular biology and biological significance (ed. J.P. Jost and H.P. Saluz), pp. 27-38. Birkhäuser Verlag, Basel. 


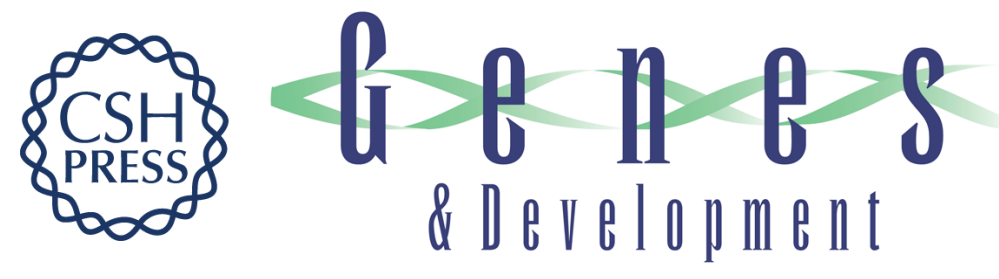

\section{Biallelic expression of imprinted genes in the mouse germ line: implications for erasure, establishment, and mechanisms of genomic imprinting.}

P E Szabó and J R Mann

Genes Dev. 1995, 9:

Access the most recent version at doi:10.1101/gad.9.15.1857

References This article cites 75 articles, 23 of which can be accessed free at:

http://genesdev.cshlp.org/content/9/15/1857.full.html\#ref-list-1

License

Email Alerting Receive free email alerts when new articles cite this article - sign up in the box at the top Service right corner of the article or click here.

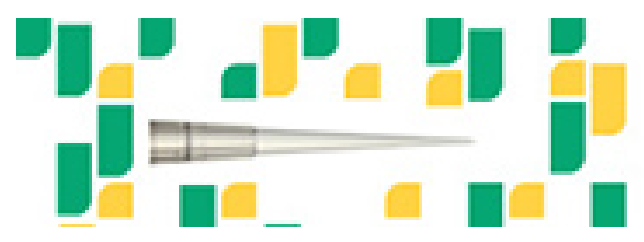

Focused on your science. 